\title{
PENELITIAN HADIS (Ontologi, Epistemologi dan Aksiologi)
}

\author{
Solihin \\ Dosen Fakultas Ushuluddin UIN Sunan Gunung Djati Bandung \\ Jl. AH. Nasution No. 105, Bandung, Indonesia \\ E-Mail: Choinsolihin65@gmail.com
}

\begin{abstract}
Study of tradition (Sunnah) becomes very urgent to do, given is strategic position as one of the principal sources of Islamic teachings. Do not just study sanad but no less important to do well against matan. Because it's central position is a study of hadith becomes important. This includes the study and understanding of the ins and out of the following hadith variety and its problems. Scientifically, the discourse requires format and accurate research methods to the study of this tradition.

This article attempts to examine how the concept of tradition of research in ontology, epistemology and axiology, to then the study of hadith through research models type sanad and matan. The hope will give its own repertoire of how each researcher have the clarity of the concept in researching the traditions to be grounded.
\end{abstract}

Keywords:Hadis; Axiology; Epistemology; Ontology; Research.

\begin{abstract}
Abstrak
Kajian terhadap hadis menjadi sangat urgen untuk dilakukan, mengingat posisinya yang strategis sebagai salah satu sumber pokok ajaran Islam. Bukan hanya kajian sanad saja tetapi tak kalah penting dilakukan juga terhadap matan.Oleh karena itu posisi sentral inilah penelitian terhadap hadis menjadi penting dilakukan. Hal tersebut meliputi kajian dan pemahaman terhadap hadits berikut ragam seluk beluk dan problematikanya. Sebagai sebuah acana ilmu maka dibutuhkan format dan metode penelitian yang akurat terhadap kajian hadis ini.

Artikel ini mencoba untuk mengkaji bagaimana konsep penelitian hadis secara ontologi, epistemologi maupun aksiologinya, untuk kemudian diarahkan pada model kajian hadis melalui penelitian sanad dan matan. Harapannya akan memberikan khasanah tersendiri bagaimana setiap peneliti memilki kejelasan konsep dalam meneliti hadis agar bisa membumi.
\end{abstract}

Kata Kunci: Hadis; Ontologi; Aksiologi; Penelitian.

\section{A. PENDAHULUAN}

Seluruh umat Islam telah menerima faham, bahwa Hadis Rasulullah Saw.itu sebagai pedoman hidup yang utama setelah al-Qur'an. ${ }^{1}$ Atau dengan kata lain Hadis Nabi merupakun sumber ajaran Islam, di samping al-Qur'an. ${ }^{2}$ Namun demikian periwayatan Hadis dan Penulisan Hadis Jauh berbeda dengan periwayatan dan Penulisan al-Qur'an. Untuk al-Qur'an, semua periwayatan ayatayatnya berlangsung secara mutawattir. Sedangkan periwayatan Hadis, sebagian dilakukan secara mutawattir dan sebagian lagi berlangsung secara ahad. ${ }^{3}$ Dengan

1 Fathurohman, Musthalahatul Hadis (Bandung: Al-Ma'arif, 1981),1.

${ }^{2}$ H.M Syuhudi Ismail, Metodologi Penelitian Hadits Nabi, 1st edn (Jakarta: Bulan Bintang, 1992), 1.

${ }^{3}$ Secara Istilah ahli Hadits Mutawat.tir berartiberita yang diriwayatkan oleh orang banyak dengan jalan demikian dilihat dari segi periwayatannya alQur'an mempunyai kedudukansebagai qath'i al-Wurud. Sedangkan Hadis, sebagain berkedudukan qath'i al-Wurud dan sebagian lagi, bahkan terbanyak kedudukan sebagai zanni al-Wurud. ${ }^{4}$

persaksian dan pendengaran yang tidak mungkin bersepakat untuk bohong dikarenakanJumlahnya banyak, keadilannya, jelas kedudukannya, dan bersambung thabaqatnya Ahad secara istilahi adalah apa yang disampaikan oleh orang orang yang tidak mencapai tingkat Mutawat.tirUntuk penjelasan lebih lanjut, Lihat misalnya, Muhammad Utsman Khasyat, Mafatih Ulum Al-Hadits Wa Turuq Takhrijuhu, 3rd edn (kairo: Maktab Al Qur'an), 53-55. Mahmud Abu Rayah, Adlwa 'Ala Al-Sunnah Al Muhammadiyah, ed. by 3 (kairo: Darr al-Ma'rif),76. Muhammad Mustafa Azham, Metodologi Kritik Hadits, L (Jakarta: Pustaka Hidayah, 1992), 73-74.

${ }^{4}$ Shalahuddin Ibn Ahmad Al-Adlabi, Manhaj Naqdil Matan (Beirut: Dar Al-Afaq Al-Jadidah, 1983), 239. Maksud Qath'I al-Wurudatau Qath'I al- 
Berdasar uraian di atas, dan dilihat dari segi periwayatannya, seluruh ayat Alquran tidak perlu diteliti lagi tentang orisinalitasnya, sementara Hadis Nabi, dalam konteks yang berkategori ahad, diperlukan pengkajian dan penelitiann lebih lanjut dan mendalam Dalam penelitian ini dapat diketahui, apakah Hadis yang bersangkutan dapat dipertanggung jawabkan periwayatannya berasal dari Nabi ataukah tidak.

Demikian, maka penelitian Hadis sebagai negasi orisinalitas Hadis menjadi panting adanya. Posisi penting tersebut terlihat dari faktor-faktor yang mendorong para ulama muhadditsin melakukan penelitian tersebut. Mengenai factor-faktor penelitian ,syuhudi Ismail mengemukakan ada enam faktor ; (1) Hadis Nabi sebagai salah satu sumber ajaran Islam, (2) Tidak seluruhHadis tertulis apda zaman Nabi, (3) Telah timbul berbagai pemalsuan Hadis, (4)Proses penghimpunan Hadis memakan waktu lama, (5) Jumlah kitab yangbanyak dengan metoda penyususnan yang beragam, dan (6) adanya periwayatanHadis secara makna. ${ }^{5}$

Untuk mengetahui apakah suatu Hadis dapat dipertanggung jawabkan eorisinalannya berasal dari Nabi, diperlukan penelitian matan dan sanad Hadis yang bersangkutan. ${ }^{6}$ Dengan kata lain wilayah kajian penelitian Hadis meliputikritik sanad dan matn Hadis.

\section{B. PEMBAHASAN}

\section{Ontologi Hadis}

\section{a) Pengertian Penelitian Hadis}

Untuk mengetahui pengertian penelitian Hadis, terlebih dahulu dikemukakan pengertian sanad dan matan Hadis, demikian karena penelitian itu mencakup kritik sanad dan matan Hadis, Sanad adalah jalan

Subutialah Absolut (Mutlaq) kebenaran beritanya, sedang Zanni Al-Wurud atau Zanni Al-Subutialah nisbi atau relative (tidak mutlaq) tingkat kebenaran beritanya.Lihat juga, Subhi Shalih, Ulum Al-Hadits Wa Musthalahuhu (Beirut: Dar Al-Ilmu Li al-Malayin, 1977), 151.

5smail,7-20. Lihat juga Syuhudi Ismai, Keshahihah Sanad Hadits, 2nd edn (Jakarta: Bulan Bintang, 1995), 85.

${ }^{6}$ Ismai, 4. periwayatan yang dapatmenghubungkan matan Hadis pada Nabi, dan matan adalah sesuatu (sabda Nabi) yang mengakhiri rangkaian sanad. ${ }^{7}$ Atau pembicaraan (kalam) atau materi yang diakhiri oleh sanad yang terakhir. ${ }^{8}$ Untuk itu pengertian yang sederhana dapat dikemukakan : Penelitian Hadis dimaksud sebagai studi kritis atas sanad dan matan Hadis yang dilakukan oleh para peneliti Hadis dengan tujuan mengetahui orisinalitas Hadis, apakah ia berasal dari Nabi atau bukan, dengan menggunakan metoda-metoda tertentu.

\section{b) Wilayah Kajian (Obyek) Penelitian}

Bagian-bagian Hadis yang menjadi objek penelitian, seperti diungkap diatas ada dun macam yaitu rangakaian para periwayat yang menyampaikan riwayat Hadis (sanad), dan materi atau matan Hadis itu sendiri. Ada bebrapa halyang penting berkenaan dengan sanad dan matan Hadis tersebut yang perlu diketahui dan diperhatikan dalam penelitian ini.

1. Sanad Hadis

\section{Pandangan Ulama Tentang Sanad}

Begitu penting kedudukan sanad dalam periwayatan Hadis, demikiankarena sanad sebagai rangkaian perawi yang menghubungkan Hadis pada Nabi(sebagai sumber Hadis) Tanpanya suatu "berita" yang dinyatakan dari Nabi,bukan disebut sebagai Hadis.

Dalam hubungannya dengan pentingnya kedudukan sanad, Muhammad bin Sirrin menyatakan bahwa, "Sesungguhnya pengetahuan Hadis adalah agama;maka perhatikanlah dari siapa kamu mengambil agama itu". 9 kemudian Abdullah bin Mubarak (W.181 H/797 M) menyatakan bahwa "Sanad merupakan bagian dari agama. Sekiranya sanad Hadis tidak ada, niscaya

\footnotetext{
${ }^{7}$ Mahmud Abu Rayah, 274

${ }^{8}$ Fathurohman, 23.

${ }^{9} \mathrm{Abu}$ al-Husain Muslim bin al-Hajjaj bin
} Muslim al-Qusyairiy Al-Naisaburiy, Al-Jami'us Shahih (Shahih Muslim, ed. by Fuad Abdul Baqi (AlHalabi Wa Syurakah, 1955), juz I, 14. dikutif oleh Syuhudi Ismail, 24 
siapa saja akan bebasmenyatakan apa yang dikehendakinya". ${ }^{10}$

Pandangandiatas mengandung dua pengertian: (I) Dalam menerima atau menghadapi Hadis, kita harus meneliti para perawi yang terlibat dalam sanad hadis tsb, (2) Sanad meruapakan bagian penting dalam periwayatan, dan karenanya kedudukan suatu kitab Hadis ditentukan.

\section{Bagian-bagian Sanad yang Diteliti}

Sanad Hadis, yang secara istilahi dikatakan sebagai rangkaian para perawiyang menyampaikan kita pada matan Hadis. ${ }^{11}$ memiliki dua bagian penting: (1)Nama-nama periwayat yang terlibat dalam periwayatan Hadis bersangkutan, (2)Lambang-lambang periwayatan Hadis yang yang digunakan oleh para perawibersangkutan, seperti:

$$
\text { ( سمعت , أخبرين , كن و ان ) }
$$

\section{Matan Hadis}

Seluruh matan Hadis berkait erat dengan sanadnya, keduanya merupakan satu kesatuan yang tidak bisa dipisahkan, keberadaannya ditentukan oleh satu sama lainnya, keduanya memiliki hubungan organis dalam periwayatan Hadis. Perlunya penelititan matan Hadis bukan hanya karena keberadan matan tidak bisa dilepuskan dari sanad saja, akan tetapi juga karena dalam periwayatan matan Hadis terjadi periwayatan secara makna. Sekalipun ulama-ulama ahli Hadis telahmenentukan syarat-syarat periwayatan bilmakna, ${ }^{12}$ tidak selamanya ketentuan-ketentuan itu dapat dipenuhi dengan baik.

Dengan adanya periwayatan secara makna, maka untuk penelitian matan Hadis tertentu (selain Hadis tentang ibadah) sasaran penelitian pada umumnya tidak tertuju kepada kata perkata dalam matan itu, tapi cukup pada kandungan berita yang bersangkutan. Dan bila main yang diteliti mengandung ajaran ibadah tertentu seperti

\footnotetext{
${ }^{10}$ Al-Naisaburiy, 15.

${ }^{11}$ Nuruddin 'Itr, Al-Madkhallla'Ulum Al-Hadit (Madinah: Maktabah al-Ilmiyah, 1972), 12. dikutif oleh Syuhudi Ismail, 25.

${ }^{12}$ Muhammad Utsman Khasyat, 12. Lihat juga Muhammad Muhammad Abu Syuhbah, Difa'u An AlSunnah (kairo: Al-Azhar), 36.
}

shalat, maka penelitian mesti kata perkata. ${ }^{13}$ adanya periwayatan Hadis secara makna telah menyebabkan penelitian matan dengan pendekatan semantik tidak mudah dilakukun. Namun hal ini tidak herarti bahwa penelitian Hadis dengun pendekatan bahasa tidek perlu dilakukan. Penggunaan pendekatan bahasa dalam penelitian matan akan sangat membantu terhadap kegiatan peneltianyang berhubugnan dengan kandugan petunjuk dari matan Hadis yang bersangkutan.

Kesulitan penelitian matan disebabkan oleh beberapa faktor, yakni: (1)

Adanya periwayatan secara makna, (2) Acuan yang digunakan sebagai pendekatan tidak semacam saja. (3) Latar belakang timbulnya petunjuk Hadis tidak selalu mudah dapat diketahui, (4) Adanya kandungan petunjuk Hadis yang berkaitan dengan halhal yang berdimensi "supra rasional", dan (5) Masih langkanya kitab-kitab yang membahas secara khusus penelitian matn Hadis.

\section{Epistemologi Hadis}

Setiap Hadis mempunyai dua buah bagian, yakni isnad dan matan. ${ }^{14}$ Isnad adalah penumpuan kita kepada para parawi untuk ilmu pengetahuan Hadis, matan adalah ungkapan atau informasi yang dinisbatkan pada Nabi. ${ }^{15}$ Untuk menetapkan validitas Hadis, epistemologi penelitian bertumpu pada kaidah-kaidah dan langkah-langkah penelitian Hadis.

\section{Kaida-Kaidah Penelilian}

Menurut Syuhudi Ismail ada dua macam kesahihan sanad suatu Hadis, yakni kaidah mayor dan kaidah minor. Kaidah kesahihan sanad adalah segala syarat atau kriteria yang harus dipenuhi oleh suatu sanad Hadis yang berkualitas sahih. ${ }^{16}$ Segala syarat atau kriteria yang bersifat umum disebut kaidah mayor, sedang yang bersifat khusus atau rincian-

\footnotetext{
${ }^{13}$ Ismai, 26.

${ }^{14}$ Muhammad Mustafa Azham, 61. Lihat juga, Mahmud Al-Thahan, Dasar-Dasar Ilmu Takhrij, 1st edn (Semarang: Bina Utama, 1995), 141.

${ }^{15}$ Muhammad Mustafa Azhami, 61. Mahmud AlThahan, Dasar-Dasar Ilmu Takhrij (Semarang: Bina Utama, 1995), 41.

${ }^{16}$ Syuhudi Ismail, 119.
} 
rincian dari kaedah mayor disebut kaidah minor. ${ }^{17}$

Untuk meneliti validitas sanad dan matan Hadis dapat difahami melalui

pengertian Hadis shahih. Mengulif lbnu Shalah, Syuhudi lsmail mengemukakan pengertian tersebut. ${ }^{18}$

Adapun Hadis shahih adalah Hadis yang bersambung sanadnya (sampaikepada Nabi), diriwayatkan oleh (periwayat) yang adil dan dhabith sampaiakhir sanad, (di dalam Hadis itu) tidak terdapat kejanggalan (syudzudz) dan cacat (illat).

Pengertian istilah Hadis di atas, mengandung lima kriteria kesahihan sanad dan matan Hadis, yang kemudian oleh Syuhudi Ismail ${ }^{19}$ direduksi menjadi tiga bagian: (1) Sanadnya bersambung sampai ke Nabi, (2) seluruh periwayatannya adil dan dhabith, (3) Terhindar dari syadz dan illat.

Kriteria atau syarat yang disebut dalam nomor satu dan nomor dua berhubungan dengan sanad Hadis, sedangkan syarat yang tercantum dalam nomor tiga berhubungan dengan sanad dan matan Hadis. Kelima unsur tadi kemudian dlsebul sebagai unsur-unsur kaidah mayor kesahihan sanad Hadis. ${ }^{20}$

Sedangkan unsur-unsur kaidah minor sanad, pada dasarnya merupakan derivasi dari unsur-unsur kaidah mayor, yang meliputi hal-hal berikut ini:

1. Sanad bersambung, unsur-unsur kaidah minor sanad bersambung meliputi; (l) Muttashil, (2) Marfu'.

2. Periwayat bersifat adil, mengandung unsur-unsur kaidah minor; (I) Beragama Islam, (2) Mukallaf, (3) Melaksanakan ketentuan Agama, dan (4) Memelihara muru'ah.

3. Periwayat bersifat dhabith, mengandung unsur-unsur kaidah minor, (l) Halal dengan baik Hadis yang diriwayatkannya, (2) Mampu dengan baik menyampaikan Hadis yang dihafalnya kepada orang lain,

${ }^{17}$ Syuhudi Ismail, 119.

${ }^{18}$ Syuhudi Ismail, 123-124. Facthur Rachman. Ikhtisar Musthalahul Hadits, 95, Mahmud Abu Rayah, 281.

${ }^{19}$ Fathurohman, 124.
${ }^{20}$ Fathurohman, 126.
(3) Terhindar dari

Syudzdzud, dan (4) Terhindar dari Illat. ${ }^{21}$

Seperti telah disinggung di atas, bahwa unsur-unsur yang harus dipenuhi oleh suatu matan yang berkualitas shahih ada dua macam, yakni terhindar dari illat (cacat). Dengan kata lain kedua unsur tadi merupakan kaidah mayor penelitian matan Hadis, Para ulama Hadis dalam menentukan tolak ukur penelitian matan (penurunan kaidah minor dari mayor) berbeda pendapat, demikian karena tampaknya mereka kesulitan dalam memformulasikan kaidah minor penelitian mutu secara sistematis.

Meskipun begitu, ada kaidah minor yang tampaknya bisa dijadikan acuan dalam menemukan kesahihan matan Hadis, dalam konteks ini, Syuhudi Ismail.22 Mengemukakan pandangan Salahuddin al-Adlabi sebagai berikut:

1. Tidak bertentangan dengan petunjuk alQur'an.

2. Tidak bertentangan dengan Hadis yang lebih kuat.

3. Tidak bertentangan dengan akal sehat, indera, dan sejarah.

4. Susunan pernyataannya menunjukkan ciri-ciri sabda kenabian.

\section{Metoda Penelitian Hadis}

Metoda atau cara-cara meneliti validitas Hadis sanad dan matan Hadis dalam bentuk langkah-langkah penelitian Hadis, menurut pemahnman penulis terhadap buku "Metodologi Penelitian Hadis" seperti yang dipaparkan oleh Syuhudi Ismail ${ }^{23}$ meliputi tiga pokok langkah-Iangkah penelitian, yang masing-masing memiliki bagian langkah sebagai derivasi dari ketiga metode pokok tadi, yang terdiri dari:

Pertama, Melakukan Tahrijul Hadis (Sebagai Langkah awal kegaitan penelitian

${ }^{21}$ H.M Syuhudi Ismail, Kaidah-Kaidah KeShahihan Hadits, 2nd edn (Jakarta: Bulan Bintang, 1995), 127-150. lihat juga Muhammad Muhammad Abu Syuhbah,31.

${ }^{22}$ Syuhudi Ismail, 128-129.

${ }^{23}$ Ismail, Metodologi Penelitian Hadits Nabi. 
Hadis) untuk mengetahui; (I) Asal usul riwayat Hadis yang akan diteliti, (2) Seluruh riwayat Hadis Hadis yang akan diteliti, (3) Ada atau tidaknya syahid atau muttabi pada sanad yang akan diteliti. Adapun metoda ${ }^{24}$ yang digunakan adalah metoda Takhrijul Hadis bil-Lafdzi dan metode Takhrijul-Hadis bil-maudhu'.

Kedua, melakukan penelitian sanad Hadis ; langkah-langkah yang ditempati dalam tahap ini adalah:

1. Melakukan I'tibar, yaitu menyertakan sanad-sanad yang lain unluk suatu Hadis tertentu, yang Hadis itu pada bagian sanadnya tampak hanya seorang perawi saja; dan dengan menyertakan sanadsanad yang lain tersebut akan dapat diketahui apakah ada periwaytan yang lain ataukah tidak ada untuk bagian sanad dari sanad Hadis yang dimaksud. I'tibar ini dilakukan untuk menentukan ke-ghariban suatu Hadis. ${ }^{25}$ hal ini dapat dilakukan dengan membuat skema Hadis.

2. Meneliti pribadi periwayat dan metoda periwaytannya. Hal-hal yang perlu diperhalikan dalam tahap ini. ${ }^{26}$

a. Menjadikan keshahihan sebagai acuan.

b. Melakukan penelitian segi-segi pribadi periwayat, meliputi; (I) Kulaitas

prihadi periwayat, (2) kapasitas intelektual periwayat.

c. Persoalan sekitar Al-Jarh wat-ta'dil. ${ }^{27}$ Ada beberapa teori yang telah dikemukakan oleh ulama dibidangnya, yang penting bagi penelitian. Antara lain:

1. At-Ta'dil Muqaddamun 'Ala Al-Jarh. Teori ini didukung oleh minoritas ulama Hadis, diantaranya, An-Nasa'i (wafat 303H/915M).

2. Al-Jarh Muqaddamun 'Ala Al-Ta 'dil. Teori ini didukung oleh kalangan ulama Hadis: ulama fiqh dan ulama ushul fiqh.

${ }^{24}$ H.M Syuhudi Ismail, 46-49. Lihat juga, Mahmud Al-Thahan, 38.; Muhammad Utsman Khasyat, 136138.

${ }^{25}$ Fathurohman, 86.

${ }^{26}$ Syuhudi Ismail, 63,66,67dan 70 .

${ }^{27}$ Syuhudi Ismail, 77-80;;Fathurohman, 273.
3. Idza Ta 'aradha al-jaarh al-Mu 'adilu fi al-Hukmu Li al-Mu 'adli illa

idza Tsubita al-Jarhu al-Mufassaru. Teori ini didukung oleh mayoritas ulama kritik Hadis.

4. Idza Kana al-Jarhu Dha'ifan Fala Yuqbalu Jarhuhu Li al-Tsiqat. Pendukung teori ini mayoritas ulama pengkritik Hadisy

5. La Yuqbulu al-jarhu illa Ba'da alTsabuti Khasiyah al-Asybahi fi-il Majrukhin. Teori ini didukung oleh kalangan ulama ahli Hadis

d. Penelitian persambungan sanad, ${ }^{28}$ yang meliputi:

1. Identifikasi lambang-lambang metode periwayatan, sanad Hadis selain memuat nama-nama perawi, juga menunjukkan metoda periwayatan yang digunakan oleh perawi masingmasing. Identifikasi Iambang periwayatan dapat menentukan tingkat akurasi metoda periwayatan yang digunakan periwayat yang tercantum dalam sanad,

2. Mengidentifikasi hubungan periwayat dengan metode periwayatannya. Secara mudah, keadaan perawi dibagi menjadi yang tsiqah dan yang tidak tsiqah. Dalam hubungannya dengan persambungan sanad, kualitas periwayat sangat menentukan. Artinya ketinggian lambang periwaayatan tidak menentukan tingkat akurasi berita,jiku pembawanya tiduk (siqah. Namun adajuga orang yang dinilai tsiqah oleh ulama ahli kritik Hadis, dengan syarat menggunakan lambang periwayatan (hadasani atau sami'tu, sanadnya bersambung, Jika tidak, sanadnya terdapat tadlis (penyembunyian cacad).

e. Meneliti Syudzudz dan lllat.

Suatu sanad bisa mengandung syudzudz, bila sanad yang diteliti lebih dari satu buah. Salah satu langkah penelitaian yang sangat penting untuk meneliti kemungkinan adanya syudzudz suatu sanad Hadis ialah dengan

${ }^{28}$ Fathurohman, 82-84 
membanding-bandingkan semua sanad yang ada untuk matan yang tofik pembahasannya atau memiliki segi kesamaan.

Adapun langkah-langkah umuk meneliti keillatan suatu Hadis, menurut lbn al-Madini, ${ }^{29}$ ialah:

1. Menghimpun dan meneliti seluruh sanad Hadis untuk mam yang semakna, bila Hadis tersebut memikliki muttabi ataupun syahid.

2. Meneliti seluruh periwayatan dalam berbagai sanad berdasarkan kritik yang telah dikemukakan oleh para ahli kritik Hadis

\section{Penelitian Matan Hadis}

Langkah-langkah metodologis penelitian matan Hadis meliputi. ${ }^{30}$

1. meneliti matan dengan kualitas sanadnya. Penelitian ini meliputi langkah-langkah pemabahasan: (1) Meneliti matan sesudah meneliti sanad, (2) Kualitas matan tidak selalu sejalan dengan kulitas sanadnya, (3) Kaidah keshahihan matan sebagi acuan.

2. Meneliti susunan main yang semakna. Cara ini ditempuh untuk dapat mengetahui terjadinya perbedaan lafal matan Hadis yang diakibatkan oleh terjadinya periwayatan secara makna, dan untuk mengidentifikasi terjadinya jiyadah, idraj dan sebagainya, yang disebabkan oleh adanya perbedaan lafal. Dalam tahap penelitian ini dapat digunakan metode perbandingan (muqaranah) antara berbagai matan Hadis yang memiliki kesamaan tema atau ada sagi kasamaan tema.

3. Meneliti kandungan matan. Untuk tahap ini ditempuh melalui langkahlangkah:

a. Membandingkan kandungan matan yang sejalan atau tidak bertentangan.Untuk mengetahui ada atau tidaknya matan lain yang memiliki topikmasalah yang sama, ditempuh

\footnotetext{
${ }^{29}$ Fathurohman, 88.

${ }^{30}$ Fathurohman, 131-135.
}

dengan jalan Takhrijul Hadis bi alMaudhu'. Jika ada matan lain yang bertopik sama, maka matan itu perluditeliti sanadnya. Jika sanad telah memenuhi syarat, maka kegiatanmuqarannah kandugnan matan tersebut dapat dapat dilakukan. Jika hasilnyasama, maka penelitian untuk tahap awal sudah selesai. Yang pada prakteknya penelitian ini dilanjutkan dengan memeriksa penjelasan masingmasing matn diberbagai kitab syarah.

Membandingkan kandungan matan yang tidak sejalan atau tampak bertentangan. ${ }^{31}$ Dalam tahap ini, aksentuasi penelitian diperuntukkanmengatasi Hadis-Hadis yang nampak kandungannya bertentangan (mukhtalifal-Hadis atau Ta'arud alHadis).metoda yang digunakan olehpara muhadditsin dalam hal ini, antara lain apa yang dikemukakan olehIbnu Hajar AlAsqalani; (I) Al-jam'u, (2) al-Nsikh WaalMansukh, (3) at-Tarjih, dun (3) at-Tauqif

\section{Aksiologi Penelitian Hadis}

Nilai aksiologis penelitian Hadis meliputi dua aspek capaian, yakni tujuandan nilai kegunaan penelitian. Tujuan pokok penelitian Hadis baik dari segi sanadmaupun matan adalah untuk mengetahui kulitas Hadis yang diteliti. KualitasHadis sangat perlu diketahui dalam hubungannya dengan kehujahan Hadis yangbersangkutan. ${ }^{32}$ Hadis yang kualilasnya tidak memenuhi syarat tidak dapatdigunakan sebagai hujjah.

Nilaikegunaan penelitian Hadis tertumpu pada fakta intelektual bahwa penelitian terdahulu adalah produk ijtihad yang bersifat dinamis dan rekorektif merupakan salah satu upaya untuk salain mengetahui sebarapa jauh tingkatakurasi penelitian ulama terhadap hasil yang mereka leliti, juga untukmenghindarkan diri dari penggunaan dalil Hadis yang tidak memenuhi syaratdilihat dari segi kehujahannya.

1l. Penutup

\footnotetext{
${ }^{31}$ Fathurohman,141. Mengenai Metode perbandingan, Liht juga, Muhammad Mustafa Azhami, 86.

${ }^{32}$ Muhammad Mustafa Azhami, 28.
} 
Meneliti kebenaran suatu berita, merupakan bagian dari upaya membenarkan yang benar dan membatalkan yang bathil, begitu tegas Syaikh Muhammad al-Ghazali. Demikian, maka penelitian Hadis merupakan kajian yang mendalam dan kritis terhadap matan dan sanad Hadis yang bersifat dinamis dengan menggunakan metode-metode tertentu untuk menetukan validitas Hadis sebagai suatu hujjah bagi kebenaran ajaranajaran agama. Sebagai muara kebenaran hakiki. WallahuA 'lamu bi al-Sawab.

\section{SIMPULAN}

Meneliti kebenaran suatu berita, merupakan bagian dari upaya membenarkan yang benar dan membatalkan yang bathil, begitu tegas syaikh Muhammad Al-Ghazali. Demikian, maka penelitian hadis merupakan kajian yang mendalam dan kritis terhadap matan dan sanad Hadis yang bersifat dinamis dengan menggunakan metode-metode tertentu untuk menentukan validitas hadis sebagai suatu hujjah bagi kebenaran ajaranajaran agama. Sebagai muara kebenaran hakiki. Wallahu A'lamu bi al-Sawab.

\section{DAFTAR PUSTAKA}

Al-Naisaburiy, Abu al-Husain Muslim bin alHajjaj bin Muslim al-Qusyairiy, Al-Jami'us
Shahih (Shahih Muslim, ed. by Fuad Abdul Baqi (Al-Halabi Wa Syurakah, 1955)

Fathurohman, Musthalahatul Hadis (Bandung: Al-Ma'arif, 1981)

Ismail, H.M Syuhudi, Kaidah-Kaidah KeShahihan Hadits, 2nd edn (Jakarta: Bulan Bintang, 1995)

-, Keshahihah Sanad Hadits, 2nd edn (Jakarta: Bulan Bintang, 1995)

- Metodologi Penelitian Hadits Nabi, 1st edn (Jakarta: Bulan Bintang, 1992)

Mahmud Abu Rayah, Adlwa 'Ala Al-Sunnah Al Muhammadiyah, ed. by 3 (kairo: Darr alMa'rif)

Mahmud Al-Thahan, Dasar-Dasar Ilmu Takhrij, 1st edn (Semarang: Bina Utama, 1995)

Muhammad Muhammad Abu Syuhbah, Difa'u An Al-Sunnah (kairo: Al-Azhar)

Muhammad Mustafa Azhami, Metodologi Kritik Hadits, L (Jakarta: Pustaka Hidayah, 1992)

Muhammad Utsman Khasyat, Mafatih Ulum AlHadits Wa Turuq Takhrijuhu, 3rd edn (kairo: Maktab Al Qur'an)

Nuruddin 'Itr, Al-MadkhalIla'Ulum Al-Hadit (Madinah: Maktabah al-Ilmiyah, 1972)

Shalahuddin Ibn Ahmad Al-Adlabi, Manhaj Naqdil Matan (Beirut: Dar Al-Afaq AlJadidah, 1983)

Shalih, Subhi, Ulum Al-Hadits Wa Musthalahuhu (Beirut: Dar Al-Ilmu Li al-Malayin, 1977) 
